SANDIA REPORT

SAND2006-1468

Unlimited Release

Printed March 2006

\title{
Chemical Analyses of Soil Samples Collected from the Sandia National Laboratories, New Mexico Environs, 1993-2005
}

\author{
Mark L. Miller, Regina A. Deola, Heidi M. Herrera, and Hans D. Oldewage \\ Prepared by \\ Sandia National Laboratories \\ Albuquerque, New Mexico 87185 and Livermore, California 94550 \\ Sandia is a multiprogram laboratory operated by Sandia Corporation, \\ a Lockheed Martin Company, for the United States Department of Energy's \\ National Nuclear Security Administration under Contract DE-AC04-94AL85000. \\ Approved for public release; further dissemination unlimited.
}


Issued by Sandia National Laboratories, operated for the United States Department of Energy by Sandia Corporation.

NOTICE: This report was prepared as an account of work sponsored by an agency of the United States Government. Neither the United States Government, nor any agency thereof, nor any of their employees, nor any of their contractors, subcontractors, or their employees, make any warranty, express or implied, or assume any legal liability or responsibility for the accuracy, completeness, or usefulness of any information, apparatus, product, or process disclosed, or represent that its use would not infringe privately owned rights. Reference herein to any specific commercial product, process, or service by trade name, trademark, manufacturer, or otherwise, does not necessarily constitute or imply its endorsement, recommendation, or favoring by the United States Government, any agency thereof, or any of their contractors or subcontractors. The views and opinions expressed herein do not necessarily state or reflect those of the United States Government, any agency thereof, or any of their contractors.

Printed in the United States of America. This report has been reproduced directly from the best available copy.

Available to DOE and DOE contractors from

U.S. Department of Energy

Office of Scientific and Technical Information

P.O. Box 62

Oak Ridge, TN 37831

Telephone: (865) $576-8401$

Facsimile: (865) $576-5728$

E-Mail: $\quad$ reports@adonis.osti.gov

Online ordering:http://www.osti.gov/bridge

Available to the public from

U.S. Department of Commerce

National Technical Information Service

5285 Port Royal Rd.

Springfield, VA 22161

Telephone: (800) 553-6847

Facsimile: (703) 605-6900

E-Mail: $\quad$ orders@ntis.fedworld.gov

Online order: $\quad$ http://www.ntis.gov/help/ordermethods.asp?loc=7-4-0\#online

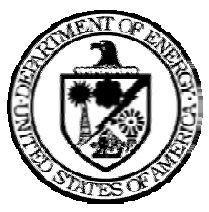


SAND2006-1468

Unlimited Release

Printed March 2006

\title{
Chemical Analyses of Soil Samples Collected from the Sandia National Laboratories, New Mexico Environs, 1993-2005
}

\author{
Mark L. Miller, Regina A. Deola \\ Environmental Management Department \\ Heidi M. Herrera \\ ES\&H Performance Assurance \\ Hans D. Oldewage \\ Emergency Response Systems Engineering \\ Sandia National Laboratories \\ P.O. Box 5800 \\ Albuquerque, NM 87185-1042
}

\begin{abstract}
From 1993 through 2005, the Environmental Management Department of Sandia National Laboratories in Albuquerque, New Mexico (SNL/NM), has collected soil and sediment samples at numerous locations on-site, on the perimeter, and off-site for the purpose of determining potential impacts to the environs from operations at the Laboratories. These samples were submitted to an analytical laboratory for metal-in-soil analyses. Intercomparisons of these results were then made to determine if there was any statistical difference between on-site, perimeter, and off-site samples, or if there were year-to-year increasing or decreasing trends which indicated that further investigation may be warranted. This work provided the SNL Environmental Management Department with a sound baseline data reference against which to assess potential current operational impacts or to compare future operational impacts. In addition, it demonstrates the commitment that the Laboratories have to go beyond mere compliance to achieve excellence in its operations. This data is presented in graphical format with narrative commentaries on particular items of interest.
\end{abstract}




\section{Table of Contents}

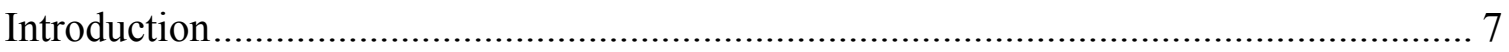

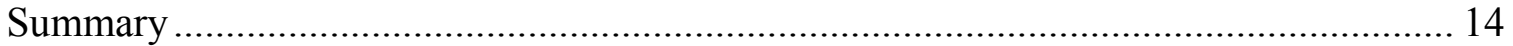

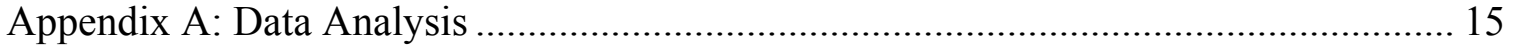

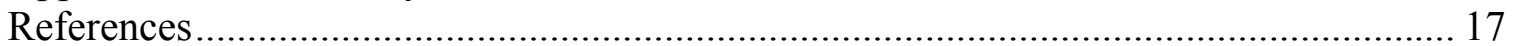

Appendix B: TAL Metals in Soil in the SNL/NM Environs............................19 


\section{Introduction}

In order to establish a baseline for trace metals that exist in the soils of Sandia National Laboratories, New Mexico (SNL/NM), from 1993 through 2005, the Environmental Management Department at SNL/NM collected soil and sediment samples at numerous locations on-site, on the perimeter, and off-site for the purpose of determining potential impacts to the environs from operations at the Laboratories. The locations are shown in Figures 1 and 2, and tabulated in Tables 1, 2, and 3. Samples were submitted to an analytical laboratory for metal-in-soil analyses (target analyte list [TAL] metals). Similar to the soil samples, sediment samples were also collected at several locations. Sediment samples sometimes can be used to determine if aggregation or concentration of contaminants in runoff can help identify trends earlier, or if they otherwise may go undetected completely. These locations are also indicated in the Tables and Figures as well and are not plotted separately.

These soil and sediment results were compared to determine if there was any statistical difference between on-site, perimeter, and off-site samples, or if there were year-to-year increasing or decreasing trends which indicated that further investigation may be warranted to ascertain the cause of the observed anomaly (Shyr, Haaker, and Herrera 1998). In some cases, the ratio between two or more elements can be used to determine if the observed concentrations are natural or anthropogenic (Hooper 2004). When more than one distribution is observed in these plots, the data are assumed to be heterogeneous (i.e., a separate source is associated with each distribution) (McLish 1994). Comparisons of these soil and sediment samples were made by media, location, and constituent following each sampling campaign, but the summary data has been pooled in this report to save space. This work provided the SNL Environmental Management Department with a sound baseline data reference against which to compare future operational impacts. In addition, it demonstrates the commitment that the Laboratories have to go beyond mere compliance, but to also achieve excellence in its operations. This data is presented in graphical format, with narrative commentaries on particular items of interest. 


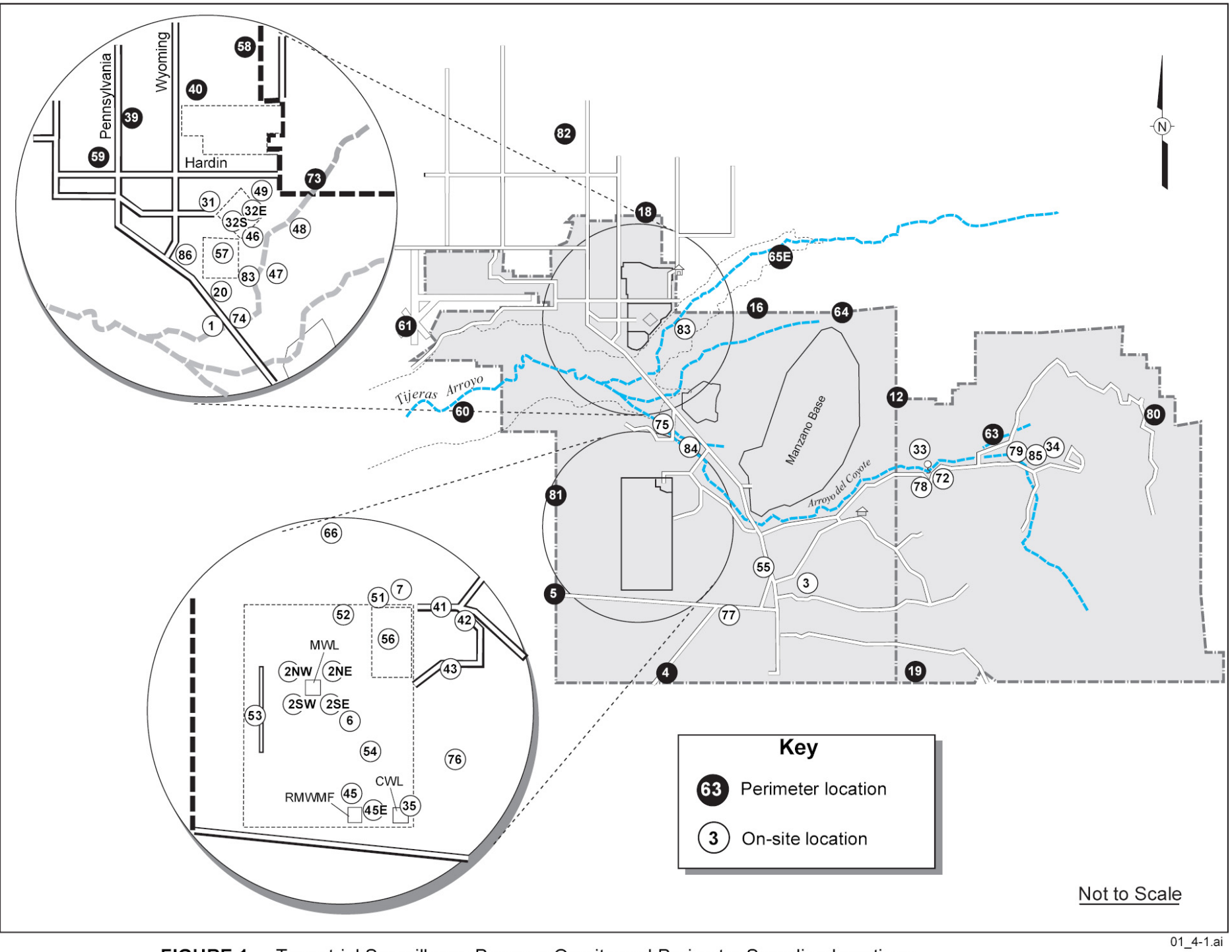

FIGURE 1. Terrestrial Surveillance Program On-site and Perimeter Sampling Locations On-site locations are within areas of SNL/NM operations. Perimeter locations are located both on and off KAFB property. 


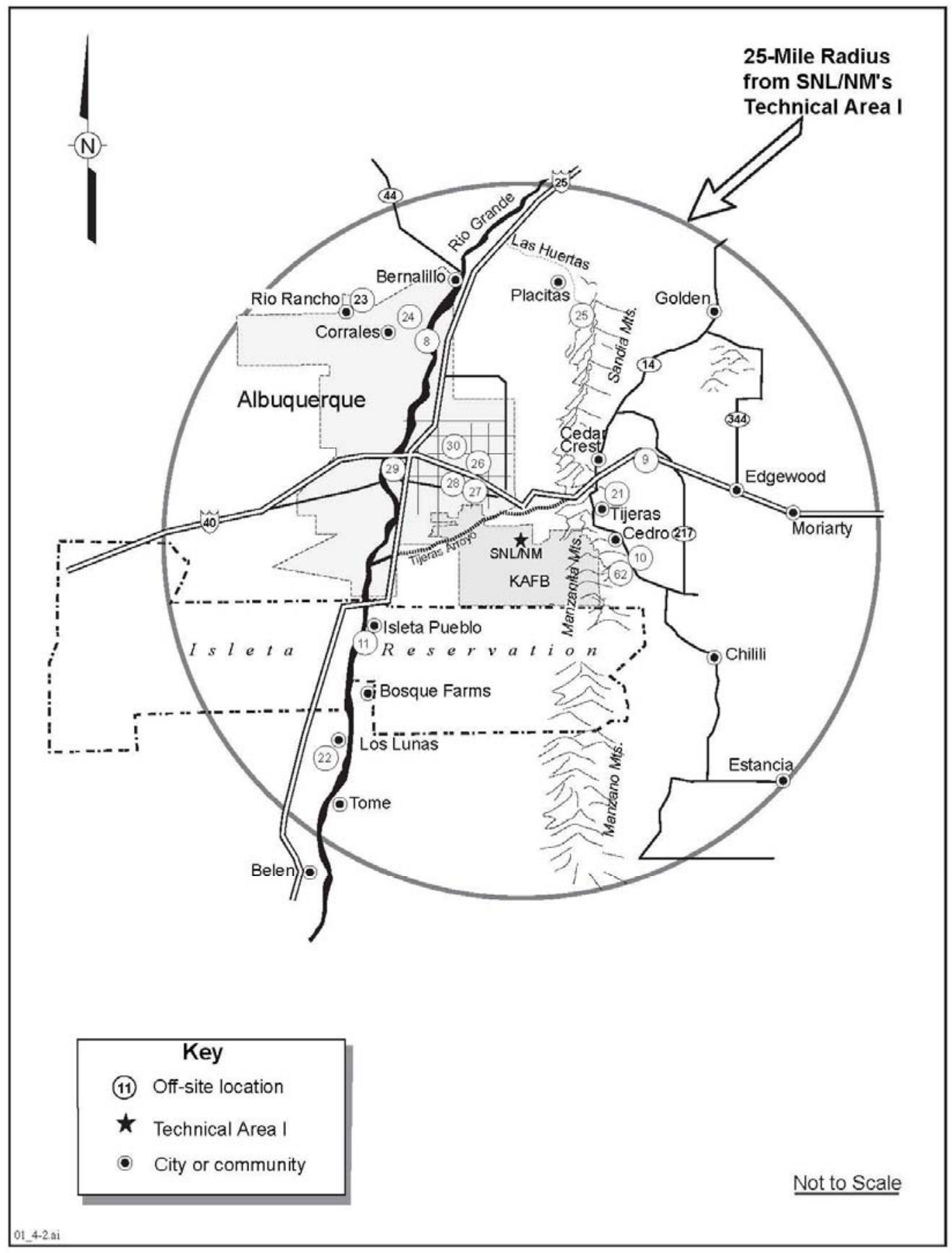

FIGURE 2. Terrestrial Surveillance Program Off-site Sampling Locations 
TABLE 1. On-site Terrestrial Surveillance Locations and Sample Types

\begin{tabular}{|c|c|c|c|}
\hline Location Number & Sampling Location & Soil & Sediment \\
\hline 1 & Pennsylvania Ave. & $\mathbf{X}$ & \\
\hline $2 \mathrm{NW}$ & Mixed Waste Landfill (MWL) (northwest) & $\mathbf{X}$ & \\
\hline $2 \mathrm{NE}$ & MWL (northeast) & $\mathbf{X}$ & \\
\hline $2 \mathrm{SE}$ & MWL (southeast) & $\mathbf{X}$ & \\
\hline $2 \mathrm{SW}$ & MWL (southwest) & $\mathbf{X}$ & \\
\hline 3 & Coyote Canyon Control & $\mathbf{X}$ & \\
\hline 6 & Tech Area (TA) III (east of water tower) & $\mathbf{X}$ & \\
\hline 7 & Unnamed Arroyo (north of TA-V) & $\mathbf{X}$ & \\
\hline 20 & TA-IV (southwest) (KAFB Skeet Range) & $\mathbf{X}$ & \\
\hline $32 \mathrm{~S}$ & TA-II, Bldg. 935 (south bay door) & $\mathbf{X}$ & \\
\hline 33 & Coyote Springs & $\mathbf{X}$ & \\
\hline 34 & Lurance Canyon Burn Site & $\mathbf{X}$ & \\
\hline 35 & Chemical Waste Landfill (CWL) & $\mathbf{X}$ & \\
\hline 41 & TA-V (northeast fence) & $\mathbf{X}$ & \\
\hline 42 & TA-V (east fence) & $\mathbf{X}$ & \\
\hline 43 & TA-V (southeast fence) & $\mathbf{X}$ & \\
\hline 45 & $\begin{array}{l}\text { Radioactive and Mixed Waste Management Facility } \\
\text { (RMWMF), TA-III (northwest corner) }\end{array}$ & $\mathbf{X}$ & \\
\hline 46 & TA-II (south corner) & $\mathbf{X}$ & \\
\hline 49 & Near the Explosive Components Facility (ECF) & $\mathbf{X}$ & \\
\hline 51 & TA-V (north of culvert) & $\mathbf{X}$ & \\
\hline 52 & TA-III, northeast of Bldgs. 6716 and 6717 & $\mathbf{X}$ & \\
\hline 53 & TA-III south of long sled track & $\mathbf{X}$ & \\
\hline 54 & TA-III, Bldg. 6630 & $\mathbf{X}$ & \\
\hline 55 & Large Melt Facility (LMF), Bldg. 9939 & $\mathbf{X}$ & \\
\hline 56 & TA-V, Bldg. 6588 (west corner) & $\mathbf{X}$ & $\mathbf{X}$ \\
\hline 57 & TA-IV, Bldg. 970 (northeast corner) & $\mathbf{X}$ & \\
\hline 66 & KAFB Facility & $\mathbf{X}$ & \\
\hline 76 & Thunder Range (north) & $\mathbf{X}$ & \\
\hline 77 & Thunder Range (south) & $\mathbf{X}$ & \\
\hline 78 & School House Mesa & $\mathbf{X}$ & \\
\hline 79 & Arroyo del Coyote (up-gradient) & & $\mathbf{X}$ \\
\hline 83 & Tijeras Arroyo GW Well & & $\mathbf{X}$ \\
\hline 84 & Storm Water Monitoring Point (SWMP)-10 & & $\mathbf{X}$ \\
\hline 85 & Arroyo del Coyote Cable Site & & $\mathbf{X}$ \\
\hline
\end{tabular}


TABLE 2. Perimeter Terrestrial Surveillance Locations and Sample Types

\begin{tabular}{|l|l|c|c|}
\hline & \multicolumn{1}{|c|}{ Sampling Location } & Soil & Sediment \\
\hline 4 & Isleta Reservation Gate & X & \\
\hline 5 & McCormick Gate & $\mathbf{X}$ & \\
\hline 12 & Northeast Perimeter & $\mathbf{X}$ & \\
\hline 16 & Four Hills & $\mathbf{X}$ & \\
\hline 19 & USGS Seismic Center Gate & $\mathbf{X}$ & \\
\hline 58 & North KAFB Housing & $\mathbf{X}$ & \\
\hline 59 & Zia Park (southeast) & $\mathbf{X}$ & \\
\hline 60 & Tijeras Arroyo (down-gradient) & $\mathbf{X}$ & $\mathbf{X}$ \\
\hline 61 & Albuquerque International Sunport (west) & $\mathbf{X}$ & \\
\hline 63 & No Sweat Boulevard & $\mathbf{X}$ & \\
\hline 64 & North Manzano Base & $\mathbf{X}$ & \\
\hline $65 \mathrm{E}$ & Tijeras Arroyo, east (up-gradient) & $\mathbf{X}$ & $\mathbf{X}$ \\
\hline 80 & Madera Canyon & $\mathbf{X}$ & \\
\hline 81 & KAFB West Fence & $\mathbf{X}$ & \\
\hline 82 & Commissary & $\mathbf{X}$ & \\
\hline
\end{tabular}

TABLE 3. Off-site Terrestrial Surveillance Locations and Sample Types

\begin{tabular}{|c|c|c|c|}
\hline Location Number & Sampling Location & Soil & Sediment \\
\hline 8 & Rio Grande, Corrales Bridge (up-gradient) & $\mathbf{X}$ & $\mathbf{X}$ \\
\hline 9 & Sedillo Hill, I-40 (east of Albuquerque) & $\mathbf{X}$ & \\
\hline 10 & Oak Flats & $\mathbf{X}$ & \\
\hline 11 & Rio Grande, Isleta Pueblo (down-gradient) & $\mathbf{X}$ & $\mathbf{X}$ \\
\hline 25 & Placitas Fire Station & $\mathbf{X}$ & \\
\hline 62 & East resident & $\mathbf{X}$ & \\
\hline
\end{tabular}


Results of the soil and sediment samples were evaluated using probability plotting, which provided a visual representation of the entire data set for all locations and for all times sampled. If the results were similar, or fit a linear distribution when plotted on logarithmic or log-probability scales, then the results were attributable to natural origin. Summary statistics for each element was imbedded in each plot. If any samples indicated concentrations greater than expected from the rest of the sample distribution, further evaluation was conducted to determine if SNL/NM facility operations were possibly responsible for the observed result. Table 4 provides various reference values for metalsin-soil. Applicable NMED Screening Levels (if available) for Industrial and Residential use are indicated on the graphs.

Appendix A contains a detailed description of the mechanics of log-normal plotting. Appendix B contains the plots of the soil/sediment data, sorted alphabetically by analyte name. Associated with each plot presented are the summary statistics for each analyte. 
Table 4. Various Reference Values for Metals-in-Soil

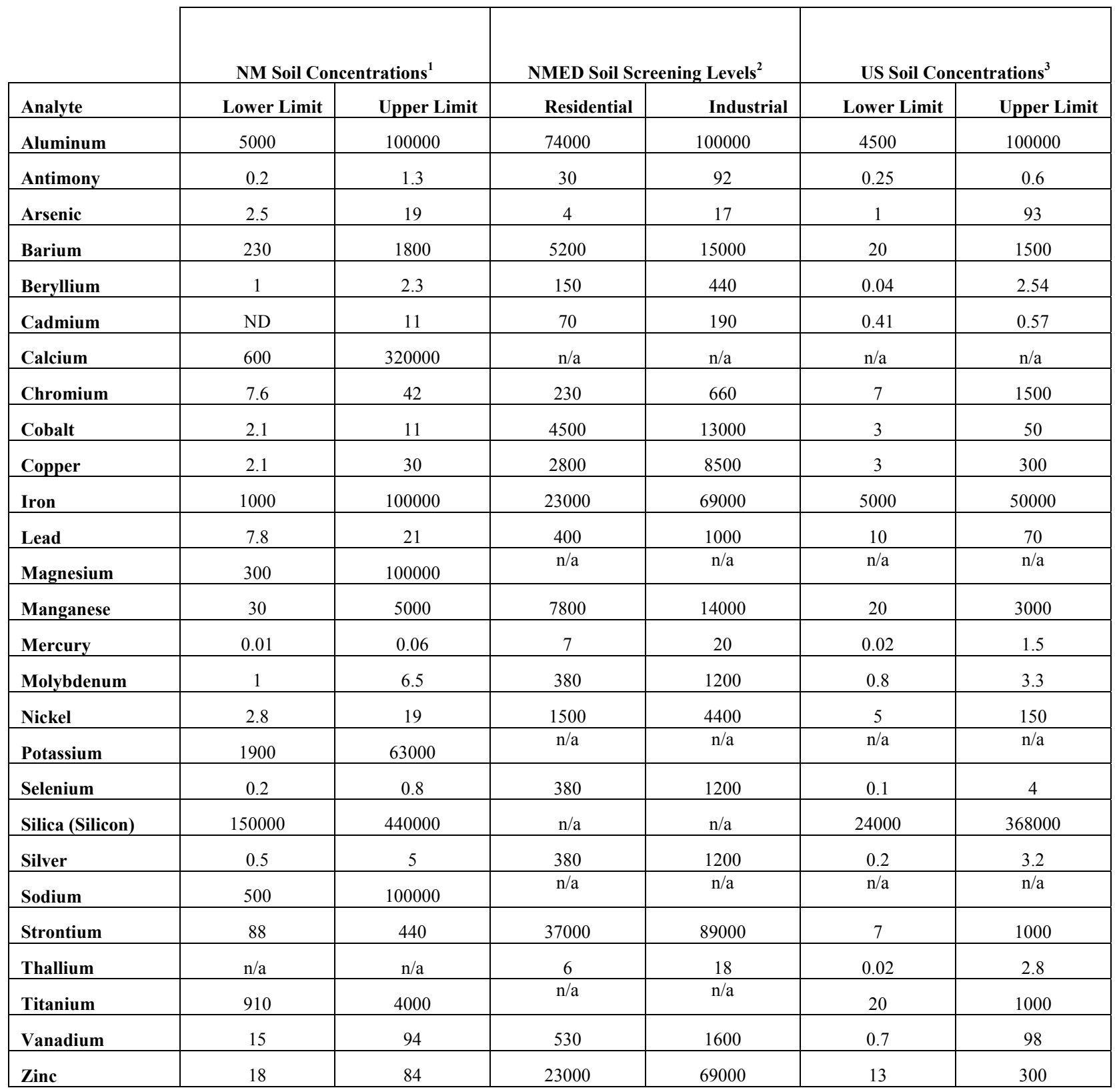

$\mathrm{ND}=$ not detectable

$\mathrm{n} / \mathrm{a}=$ not available

(1) Dragun, James, A. Chiasson, Elements in North American Soils, 1991, Hazardous Materials Control Resources Institute, (Used San Juan Basin, A Horizon to determine values).

(2) NMED Soil Screening Levels (SSL), New Mexico Environmental Department Hazardous Waste Bureau and Ground Water Quality Bureau Voluntary Remediation Program, Technical Background Document for Development of Soil Screening Levels, NMED 2000

(3) US Soil Surface Concentrations

Kabata-Pendias, A., Pendias, H., CRC, Trace Elements in Soils and Plants, 2nd Edition, 1992 


\section{Summary}

Soil and sediment samples have been collected from 1993 through 2005 at SNL/NM as one means of monitoring for the potential effects on the environment of facility operations at the Laboratories. The year-to-year results of this sampling effort are reported in the Annual Site Environmental Report (ASER, SNL 2005a). With the exception of a few locations, the data indicate that SNL/NM operations have made no significant impact to existing concentration of TAL metal in surface soil or sediment.

The only significant exception was noted at sampling location \#20, immediately west of Technical Area IV (TA-IV). Here, elevated levels of As, $\mathrm{Sb}$ and Pb were detected. As it turns out, the $\mathrm{As}, \mathrm{Sb}$ and $\mathrm{Pb}$ did not originate from $\mathrm{SNL} / \mathrm{NM}$ operations, but coincidentally from the nearby Skeet Range operated by the Kirtland Air Force Base (KAFB) for many years. The Skeet Range has now been remediated and is no longer used (Montgomery-Watson 2001). The New Mexico Environment Department determined that this remediation was sufficient for No Further Action (Lundstrom 2003). Furthermore, comprehensive analysis of the data collected from this location corroborates that the low levels of residual $\mathrm{As}, \mathrm{Sb}$, and $\mathrm{Pb}$ at this location present no future risk to human health or the environment (SNL 2005b). 


\section{Appendix A - Data Analysis}

The data in this report is presented in the form of log-normal probability plots. Such plots are useful tools for conveniently cataloguing and evaluating large amounts of data, as well as providing a first approximation of the similarity (or differences) of the data. The basis for using log-normal plotting is experience which has shown that large quantities of environmental data (many similar analyte/media combinations) yield a straight line when plotted on a log-probability or logarithmic scale (Miller 1977). The presumption of log-normal distribution is never a bad presumption and is never worse than the presumption of arithmetic-normal (Michels 1971). Because the data is represented graphically, the mean, standard deviation, expected upper limits, and any abnormalities can be readily determined visually (Waite 1975).

Characteristics of special importance in the use of log-normal plots are linearity (denoting data from a common population), standard geometric deviation ( $\sigma_{\mathrm{g}}$, an indicator of variability or range), and geometric mean $\left(\mathrm{X}_{\mathrm{g}}\right)$. The usit of slope in a log-normal plot involves a logarithmic increment. Thus, the standard deviation is a multiplier of the geometric mean (Michels 1971). The values for $\sigma_{\mathrm{g}}$ and $\mathrm{X}_{\mathrm{g}}$ can be obtained from the graphs by the ratio of the $84 \% / 50 \%$ intercepts and the $50 \%$ intercepts, respectively (Miller 1977). Linearity of the graph implies that any potential SNL/NM contribution to the observed concentration is indistinguishable from regional levels of the element. Anomalous results (potentially attributable to SNL/NM operations) must necessarily occur at a higher concentration than would be expected from regional distributions. For convenience, summary statistics for each element was imbedded in each plot. Included in this list is the Upper Tolerance Limit (UTL), which is defined as:

$$
95^{\text {th }} \mathrm{UTL}=\overline{\mathrm{X}}+\mathrm{K} * \mathrm{~S}
$$

Where $\underline{\mathrm{UTL}}=$ Upper Tolerance Limit

$\mathrm{X}=$ Sample Arithmetic Mean

$\mathrm{S}=$ Sample Standard Deviation

$\mathrm{K}=$ One-sided normal tolerance factor

Values for $\mathrm{K}$ are commonly determined from tables such as those provided by Lieberman (Leiberman 1958). A typical value of $\mathrm{K}$ equal to 1.763 was assigned, which is for sample size of $n=500$. The sample size for each element ranged from 500-1100. This UTL can be used to estimate a level above which a sample result may not be attributable to naturally occurring "background" levels of the element.

Whenever a particular results appears elevated (on the log-normal plot) compared to the expected concentration based on the population comprised of all the other locations, further investigation to determine if SNL/NM operations are potentially responsible may include (but should not be limited to) the following: 
- What is the geographical location of the sample? Is there a detectable pattern to the anomalous observation or is the sample from an area in close proximity to a facility which has the potential for release of the analyte or contaminant?

- Does the location of the sample(s) show elevated levels for other analytes or for the results obtained from the same location in previous years?

- If several locations appear to be elevated, is there a particular year that had the elevated results? How did these compare to perimeter or off-site sample results?

As can be observed in many of the graphs, data at the lower end of the range frequently "falls off" in a manner that suggests that these results do not belong in the distribution being plotted, or are otherwise anomalous. However, in almost all instances, these results represent reported values that were at the extreme lower limit of the analytical method employed at the time of analysis. This is not atypical, since the plotted values do not include the analytical uncertainty or method detection level (MDL) for a given result. Also, the MDL changes (frequently becomes better) over time as the state-of-the-art for analytical science improves, and the aggregated data may include data that actually has a range of MDLs, which only becomes an artifact if the given analyte's concentration is near the MDL. In several of the plots, many of the same reported values appear as a "flat line". These values are typically the "less than" values reported by the laboratory when the analyte was not otherwise detected.

Appendix B contains the plots of the soil/sediment data, sorted alphabetically by analyte name. Any noteworthy anomalies in the plots are discussed by notes within the given plot. Associated with each plot presented in Appendix B are the summary statistics and NMED Screening Levels for each analyte. 


\section{References}

Dragun and Dragun, J. and K. Chekiri, Elements in North American Soils. The Association for Environmental Chekiri Health and Sciences, Amherst, MA (2005).

IT Corp 1996, Background Concentrations of Constituents of Concern to the Sandia National Laboratories/New Mexico, Environmental Restoration Project. (IT Corp). (1996).

Kabata- Pendias and Pendias 2002, Trace Elements in Soils and Plants, 3rd. Ed. CRC Press, Inc., Boca Raton, FL (2002).

Hooper 2004. Industrial Hygiene Investigation Report, IHIR \# IR2004-281, December 2004.

Lieberman, G.J., 1958, “Tables for One-Sided Statistical Tolerance Limits,” Industrial Quality Control, Vol. 14, No. 10.

Lundstrom, 2003. Letter from Mr. Charles Lundstrom, Director, NMED Water \& Waste Management Division to Mr. Carl Lanz, Chief, Environmental Management Branch, Restoration Section, KAFB. August 2003.

McLish, T.J., L.C. Hall, L.L. Berg (1994), "Evaluation of Metals and Radiologic Parameters in Surface Soil at Site 300" Appendix P - Data to support Baseline Risk Assessment in "Final Site-Wide Remedial Investigation Report Lawrence Livermore National Laboratory Site 300, UCRL-AT-108131.

Michels, D.E. (1971) "Log-normal Analysis of Data for Plutonium in the Outdoors", LA4756, Los Alamos National Labs, 1971.

Miller, M.L., Fix, J.L. and Bramson, P.E 1977. Radiochemical Analyses of Soil and Vegetation Samples Taken for the Hanford Environs, 1971-1976. BNWL-2249.

Montgomery-Watson, 2001. No Further Action Proposal for Corrective Action Units OT-86, Former Small-arms Ranges (OT-86), and SS-83, Skeet Range and Landfill Road (SS-83). Albuquerque, New Mexico. April 2001.

Shyr, Herrera and Haaker 1998. The Role of Data Analysis in Sampling Design of Environmental Monitoring, SAND98-0612. Sandia National Laboratories, Albuquerque, NM (March 1998).

SNL 2005a. Annual Site Environmental Report for Sandia National Laboratories, New Mexico, SAND2005-4594, September 2005. 
SNL 2005b. Internal Memorandum from Mark Miller to Su Hwang, Summary of the KAFB Skeet Range and Residual Lead (Pb) Shot at SNL Terrestrial Surveillance Location \#20, September 2005.

Waite, D.A., and Bramson, P.E. 1975. Interpretation of Near Background

Environmental Surveillance Data by Distribution Analysis, IAEA-SM-202/706, Battelle, Pacific Northwest Laboratories, Richland, WA. 


\section{Appendix B - TAL Metals in Soil in the SNL/NM Environs}
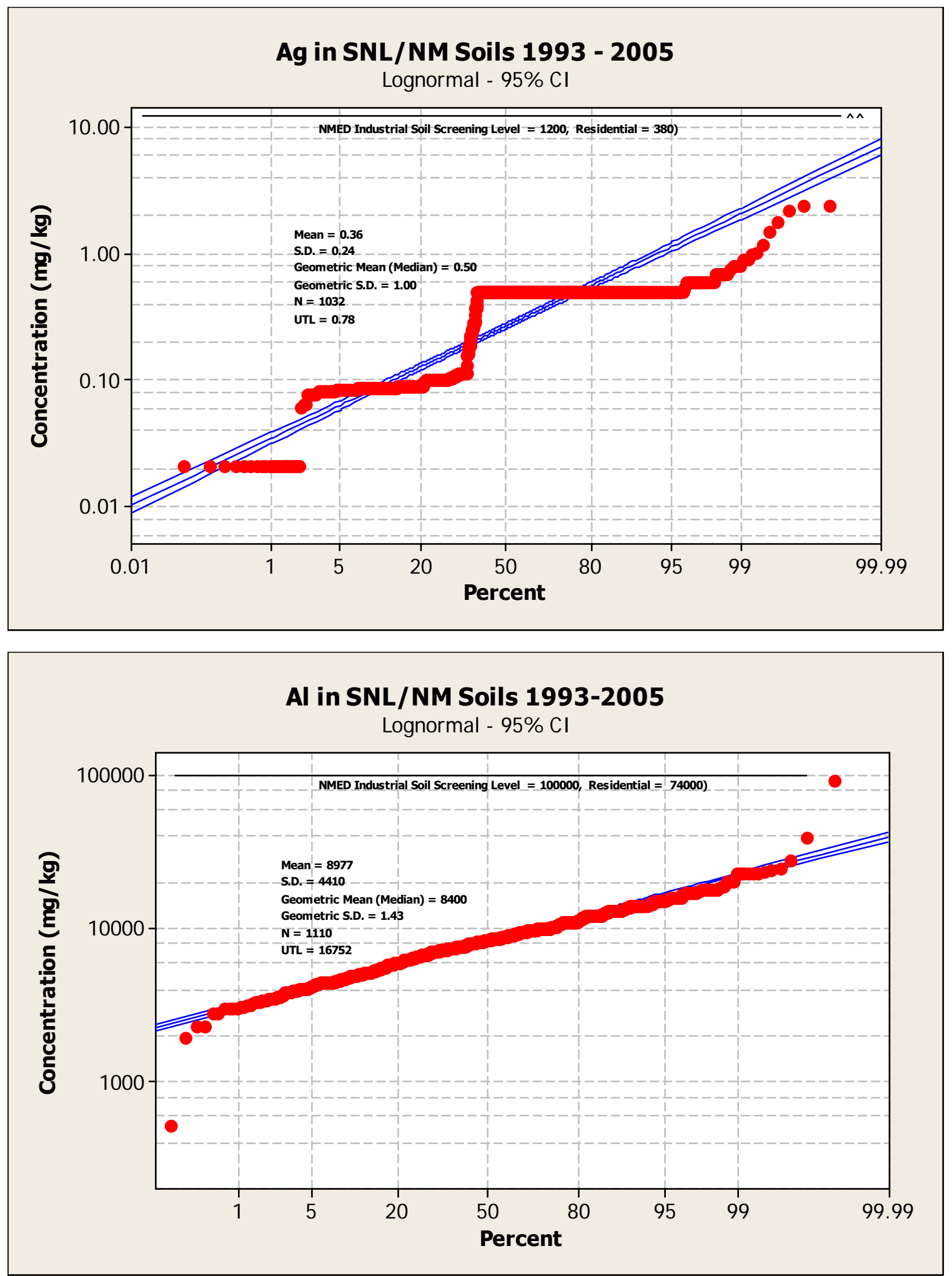

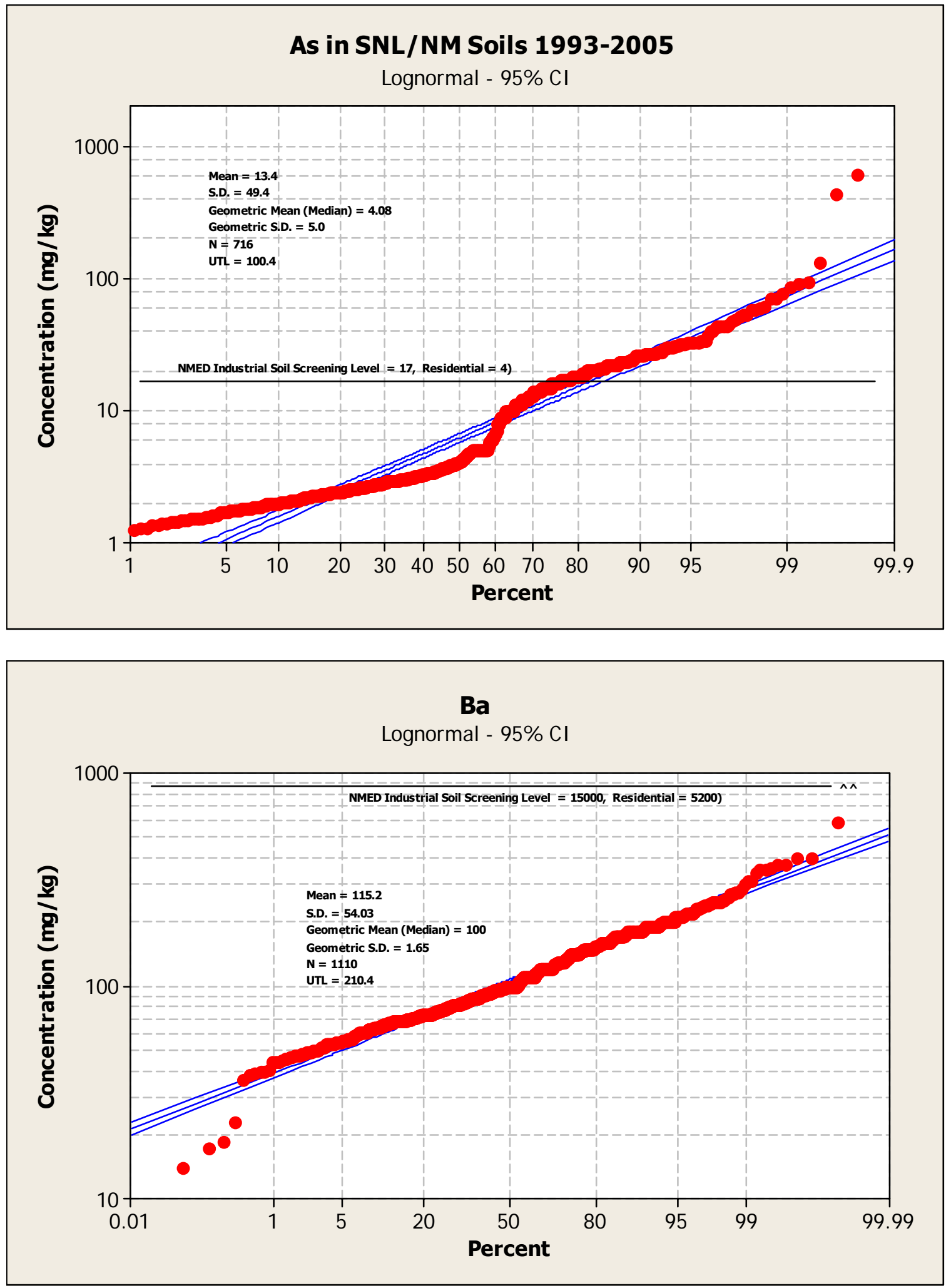

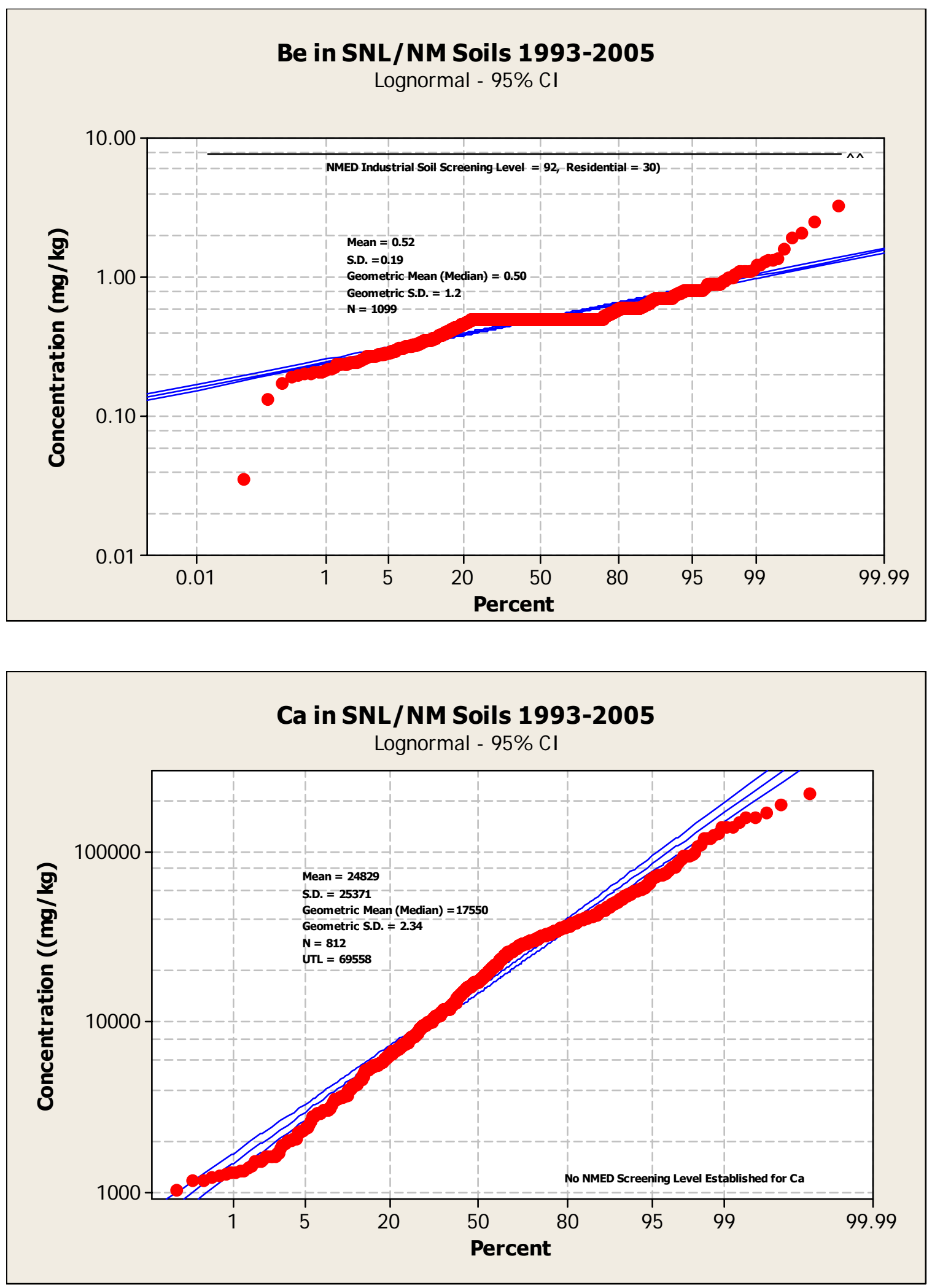

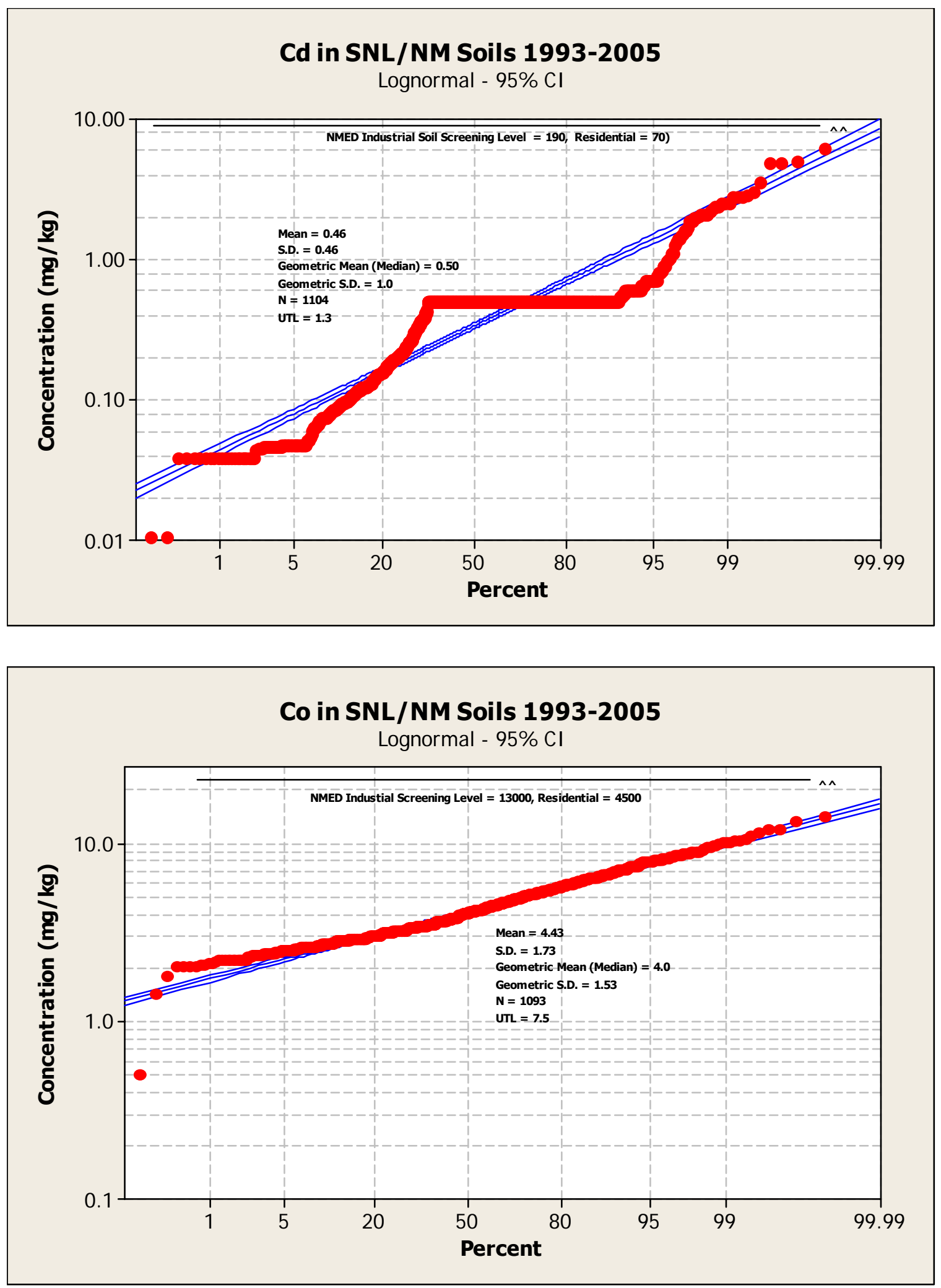

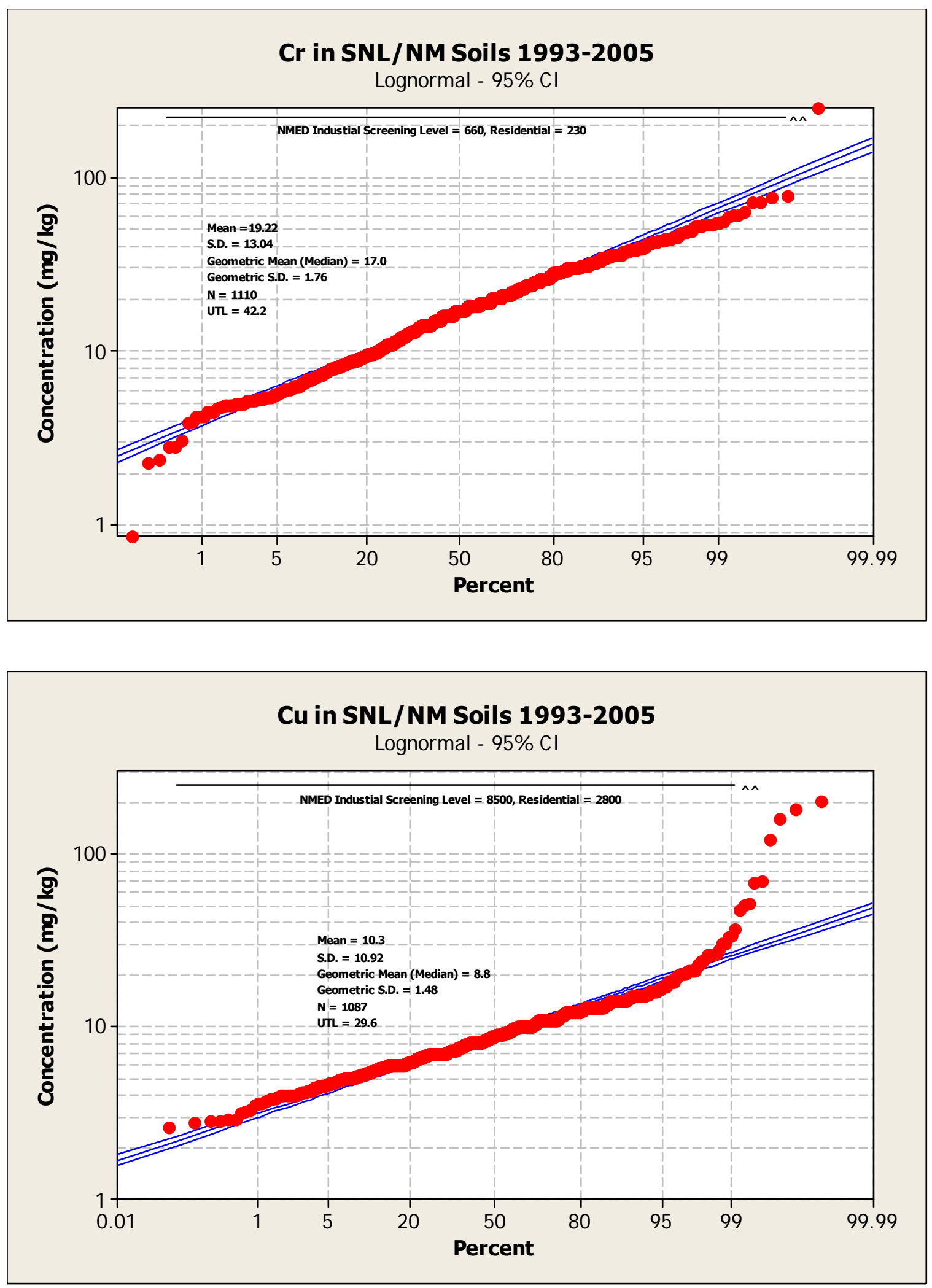

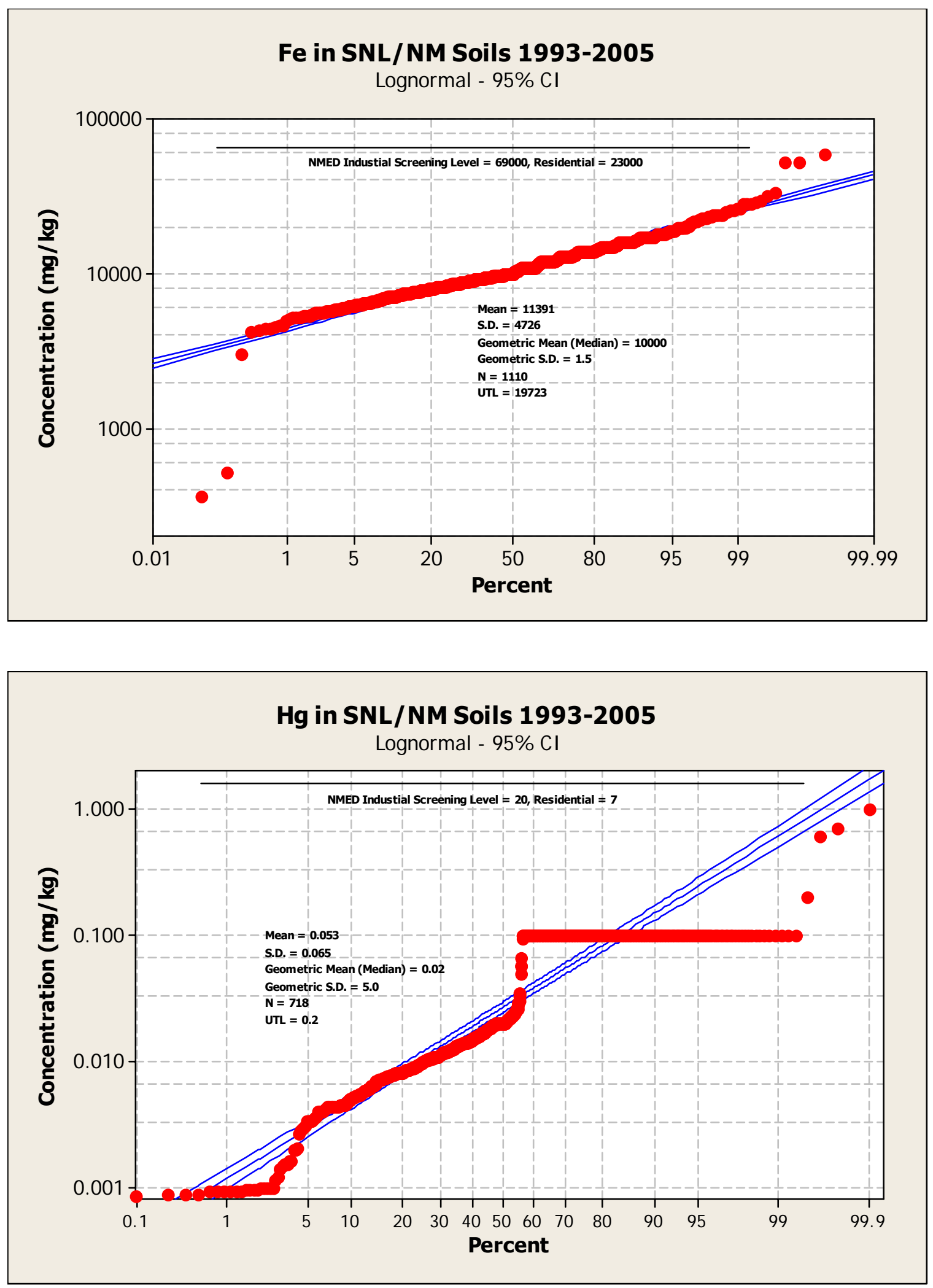

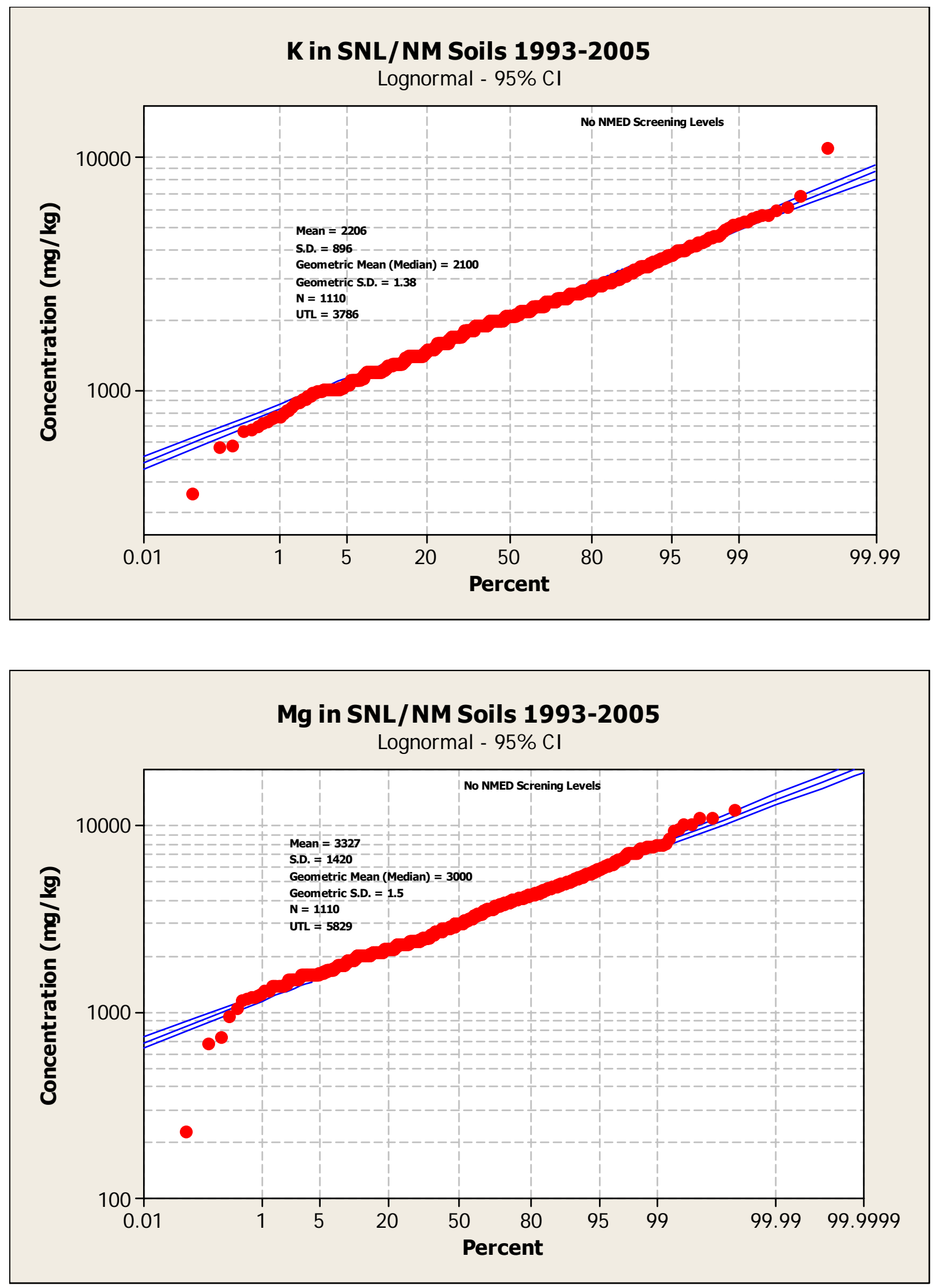

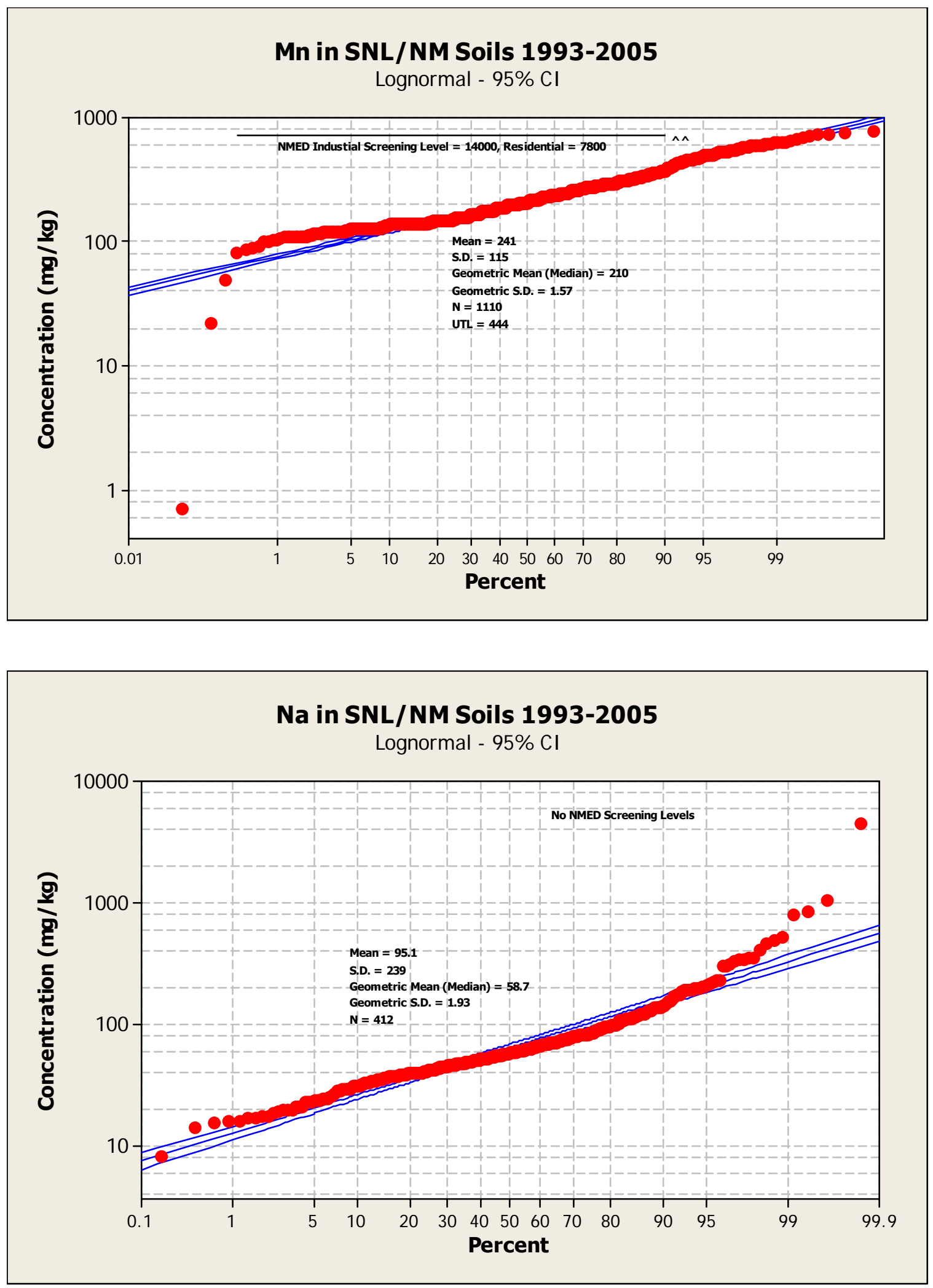

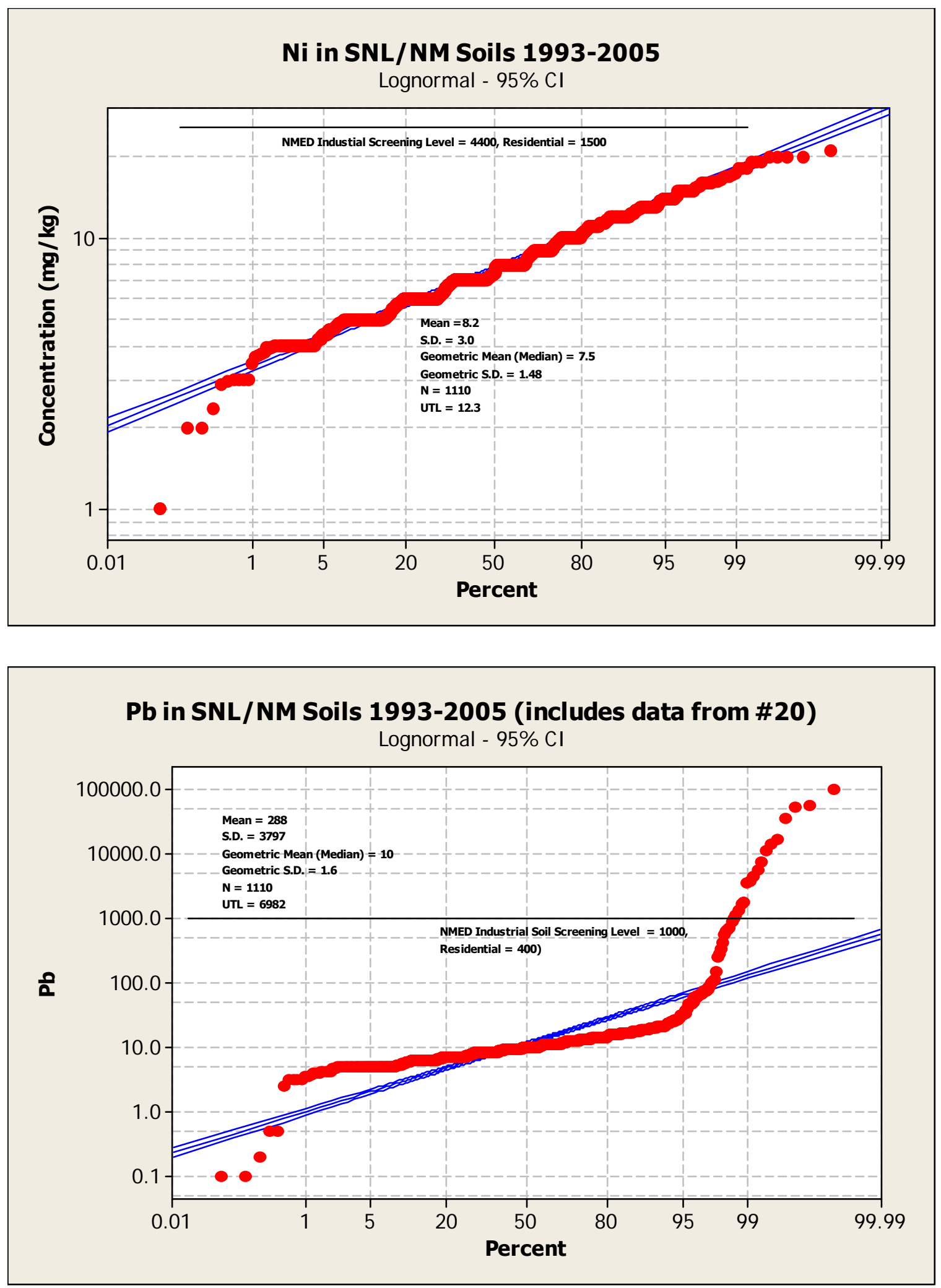

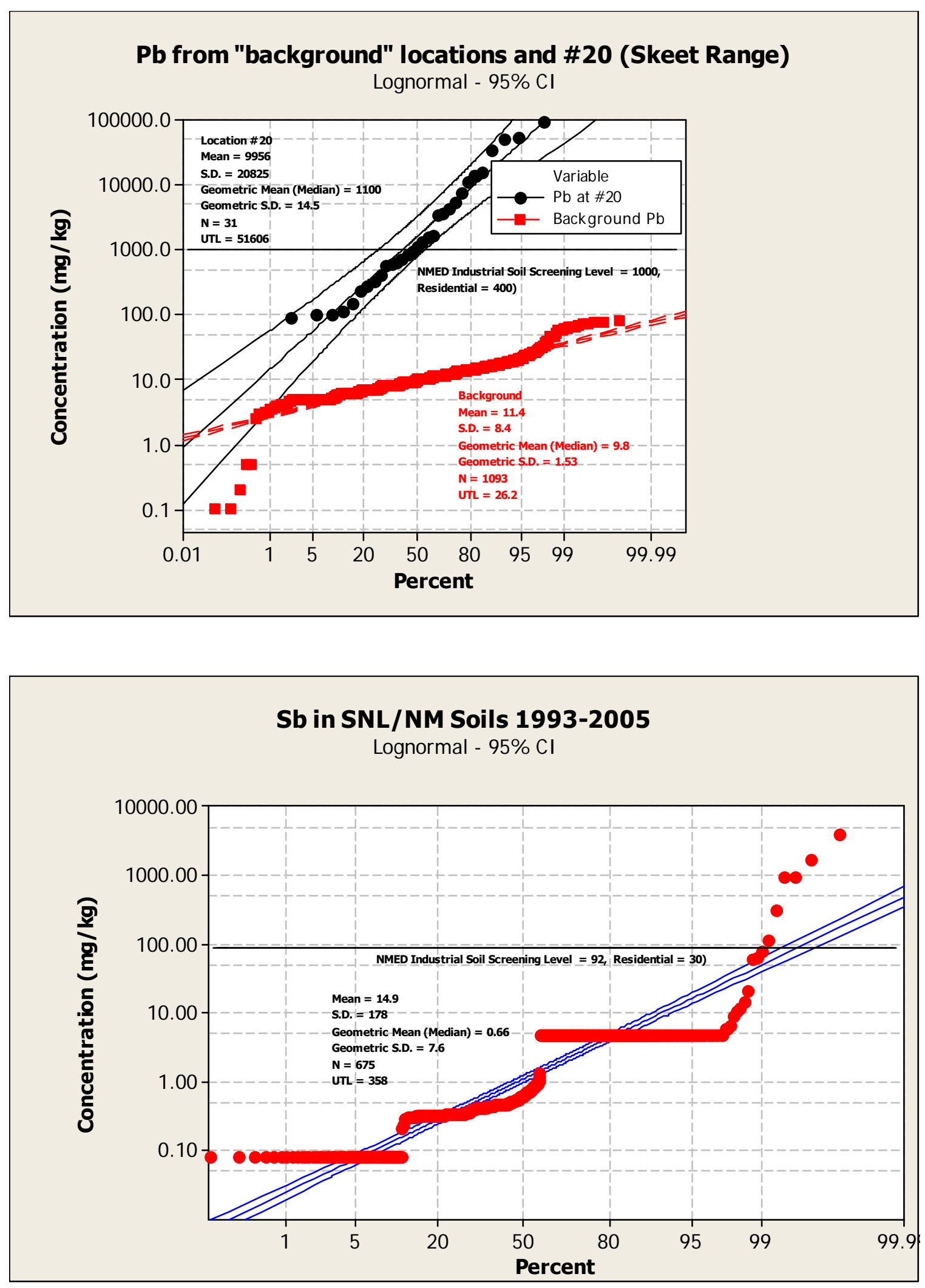

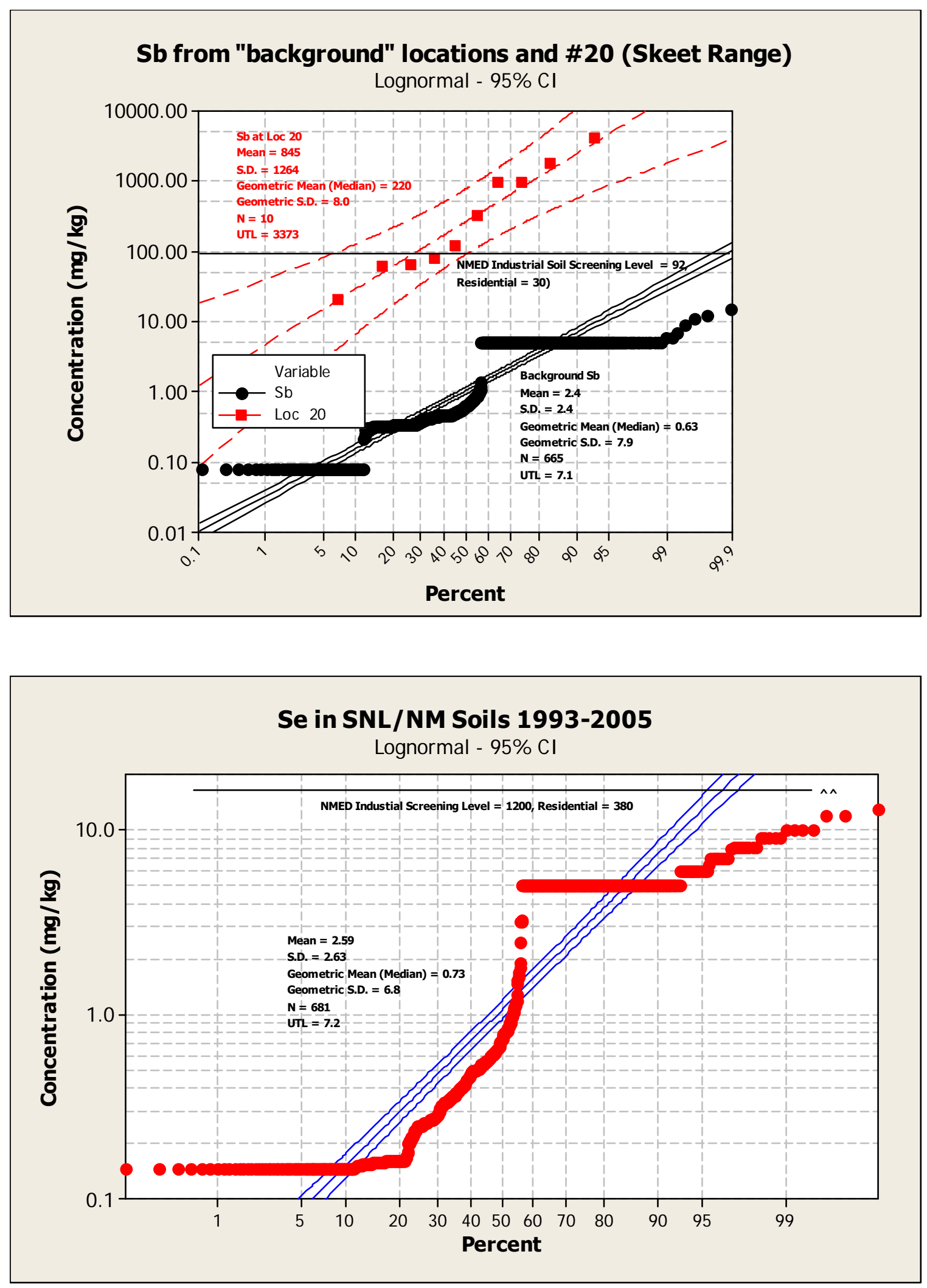

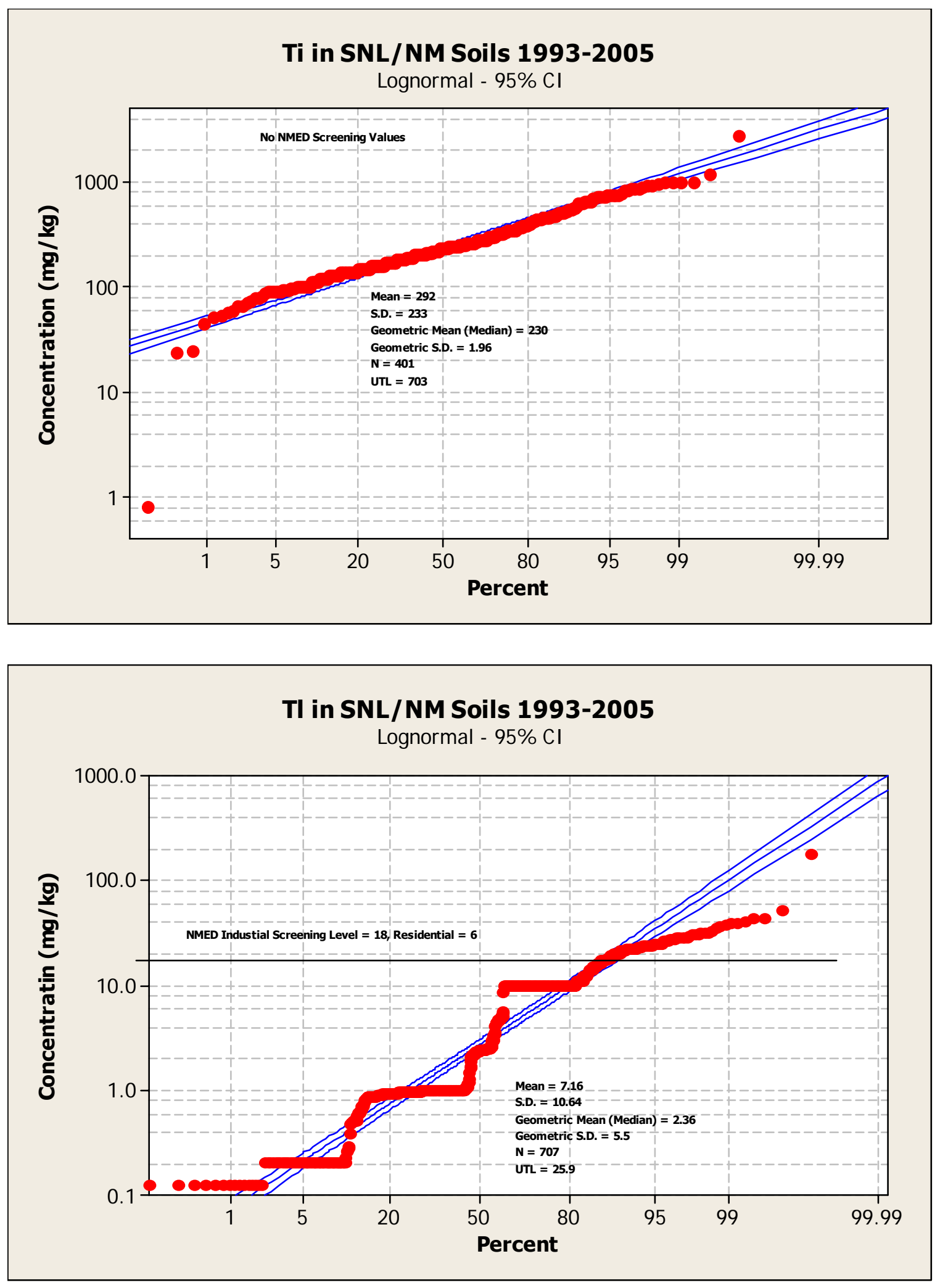

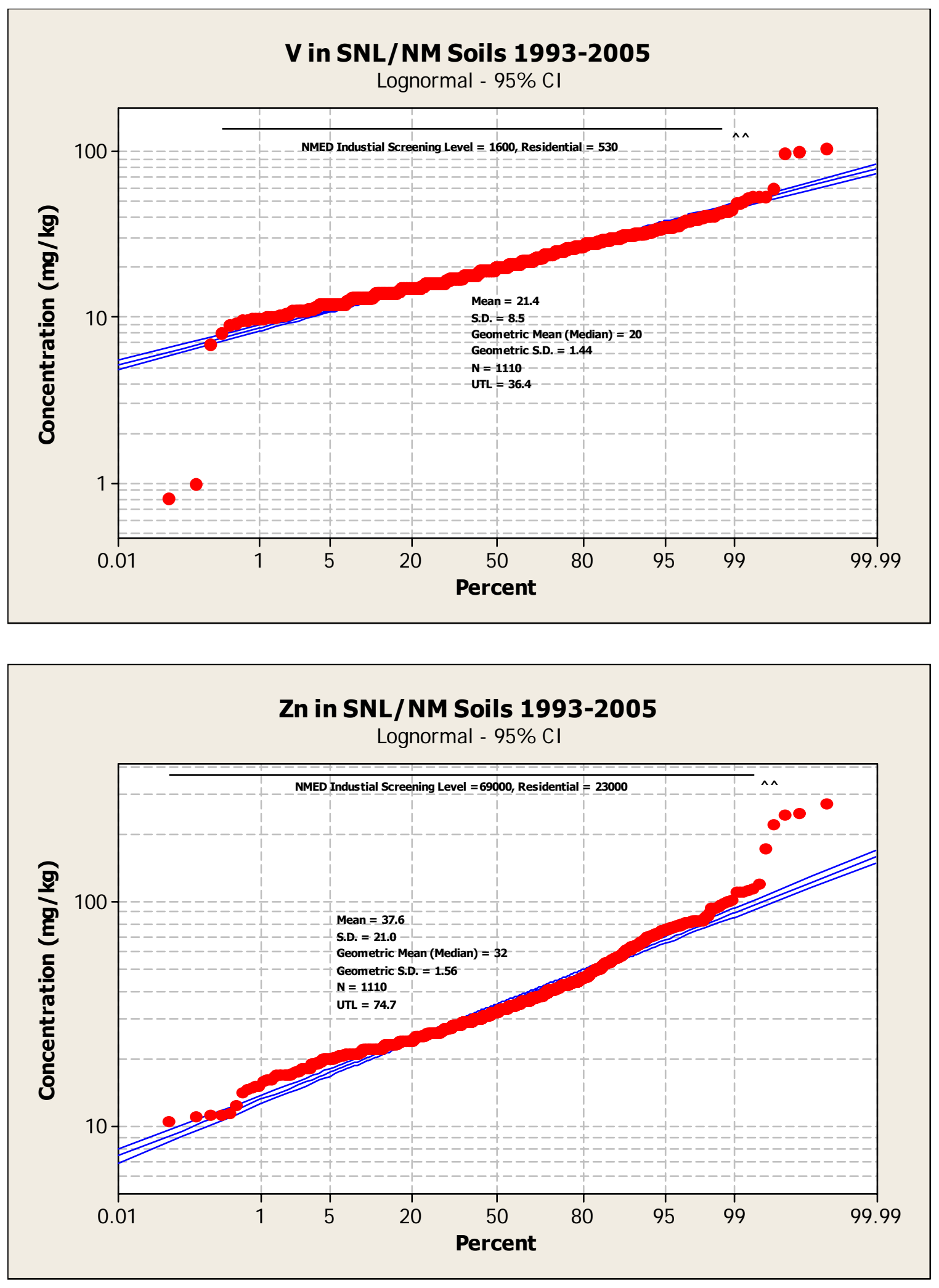


\begin{tabular}{llll} 
& & \multicolumn{2}{c}{ Distribution } \\
1 & MS1042 & Mark Miller & 10331 \\
1 & MS1042 & Regina Deola & 10331 \\
1 & MS0890 & Heidi Herrera & 10312 \\
1 & MS0491 & Hans Oldewage & 123451 \\
1 & MS0184 & Karen Agogino & SSO \\
1 & MS0184 & Susan Lacy & SSO \\
2 & MS9018 & Central Technical Files & $8945-1$ \\
2 & MS0899 & Technical Library & 4536
\end{tabular}

